\title{
The relative influence of nutrients and habitat on stream metabolism in agricultural streams
}

\author{
Jill D. Frankforter • Holly S. Weyers • \\ Jerad D. Bales • Patrick W. Moran • \\ Daniel L. Calhoun
}

Received: 26 January 2009 / Accepted: 27 July 2009 / Published online: 15 August 2009

(C) The Author(s) 2009. This article is published with open access at Springerlink.com

\begin{abstract}
Stream metabolism was measured in 33 streams across a gradient of nutrient concentrations in four agricultural areas of the USA to determine the relative influence of nutrient concentrations and habitat on primary production (GPP) and respiration (CR-24). In conjunction with the stream metabolism estimates, water quality and algal biomass samples were collected, as was an assessment of habitat in the sampling
\end{abstract}

J. D. Frankforter $(\varangle)$

US Geological Survey, 5231 South 19th Street, Lincoln, NE 68512, USA

e-mail: jdfrankf@usgs.gov

H. S. Weyers

US Geological Survey, 1289 McD Drive,

Dover, DE 19901, USA

e-mail: hsweyers@usgs.gov

J. D. Bales

US Geological Survey, 3916 Sunset Ridge Road,

Raleigh, NC 27607, USA

e-mail: jdbales@usgs.gov

P. W. Moran

US Geological Survey, 934 Broadway, Suite 300,

Tacoma, WA 98402, USA

e-mail: pwmoran@usgs.gov

D. L. Calhoun

US Geological Survey, 3039 Arnwiler Road, Suite 130,

Atlanta, GA 30360, USA

e-mail: dcalhoun@usgs.gov reach. When data for all study areas were combined, there were no statistically significant relations between gross primary production or community respiration and any of the independent variables. However, significant regression models were developed for three study areas for GPP $\left(r^{2}=0.79-0.91\right)$ and CR-24 $\left(r^{2}=0.76-0.77\right)$. Various forms of nutrients (total phosphorus and area-weighted total nitrogen loading) were significant for predicting GPP in two study areas, with habitat variables important in seven significant models. Important physical variables included light availability, precipitation, basin area, and in-stream habitat cover. Both benthic and seston chlorophyll were not found to be important explanatory variables in any of the models; however, benthic ash-free dry weight was important in two models for GPP.

Keywords Primary production - Respiration • Nutrient enrichment • United States • Streams • Agricultural

\section{Introduction}

Agricultural activity dominates land use across about half of the total land area of the conterminous USA (US Department of Agriculture 2002) and is the leading source of pollution in the assessed streams of the Nation, contributing to up 
to $48 \%$ of the reported water quality problems in impaired streams (US Environmental Protection Agency 2002a). Agricultural influences on stream quality have been widely documented, with nutrients, specifically nitrate, detected in concentrations generally higher in agricultural streams than streams in undeveloped (forest or rangeland) basins (Fuhrer et al. 1999; Rabalais et al. 2002; Mueller and Spahr 2006).

Resulting nutrient enrichment in streams and rivers of agricultural areas causes a variety of ecological problems, including increased biomass of aquatic plants and algae. Such increases in plant and algal biomass not only alter habitat but, following senescence, also deplete the water of dissolved oxygen (DO). Therefore, studies of nutrient enrichment in streams have typically focused on the variations in plant and algal biomass and community structure with varying nutrient concentrations (Dodds et al. 1998; Chételat et al. 1999; Biggs 2000; Royer et al. 2008) and factors that may influence these variations (Dodds et al. 2002). Often, the statistical relations between nutrients and benthic algal biomass are poor because of the numerous other biological and physical factors that influence biomass (Biggs 1996).

The photosynthetic rate or primary production, as determined by measuring diurnal changes in DO concentrations (Odum and Hoskin 1958), is useful for understanding the influence of nutrient enrichment on ecological processes in streams and may even be beneficial in the development and refinement of nutrient criteria (Dodds and Welch 2000; US Environmental Protection Agency 2000). Diurnal measures of DO and carbon dioxide $\left(\mathrm{CO}_{2}\right)$ can be used to obtain estimates of gross primary production (GPP) and 24-hour community respiration (CR-24) (Bott et al. 1978) in stream reaches (Bott 1996) and to calculate the net ecosystem production (NEP). A whole-stream approach for measuring GPP includes the contributions of patchily distributed algae, bryophytes, and vascular plants and allows for direct comparisons with other reach-scale measurements (Marzolf et al. 1994).

Numerous studies utilizing changes in DO and/or $\mathrm{CO}_{2}$ to estimate primary production and stream metabolism have been conducted in a variety of environmental settings (Odum 1956; Hall 1972; Bott et al. 1978, 1985, 2006; Wiley et al. 1990; Marzolf et al. 1994; Young and Huryn 1996; Mulholland et al. 1997; Biggs et al. 1999; Young and Huryn 1999; Hall and Tank 2003; McTammany et al. 2003; Houser and Mulholland 2005). Similarly, a small number of studies have analyzed the effect of increasing nitrate concentrations on the efficiency of biotic uptake and denitrification of nitrate, as related to ecosystem photosynthesis and respiration (Peterson et al. 2001; Duff et al. 2008; Mulholland et al. 2008). Some studies of stream metabolism along a nutrient gradient have focused on longitudinal differences in response within a single stream (e.g., Uehlinger and Brock 2005).

The objective of this study was to examine the relative influence of nutrients (nitrogen and phosphorus) and habitat on stream metabolism in agricultural landscapes. Our findings will also be presented in light of the recent efforts on the development of regional nutrient criteria by the US Environmental Protection Agency (USEPA). This study was conducted as part of the US Geological Survey's (USGS) National Water-Quality Assessment Program.

\section{Methods}

Study areas

This study was conducted in four areas (Fig. 1) that are dominated by agricultural land use, but that also represent a broad spectrum of environmental settings (climate, geology, topography, and soils) and agricultural practices (crop and animal production and irrigation and drainage practices). These four study areas included the Central Columbia Plateau-Yakima River Basin (CCYK) and Central Nebraska Basins (CNBR), which were sampled in 2003, and the Delmarva Peninsula (DLMV) and White-Miami River Basins (WHMI), which were sampled in 2004. Eastern study areas (DLMV and WHMI) are humid, with agriculture relying primarily on natural rainfall (Table 1). In contrast, western study areas (CCYK and CNBR) are in more arid environ- 
Fig. 1 Location of the stream metabolism study areas for the US Geological Survey study of nutrient enrichment effects on aquatic ecosystems

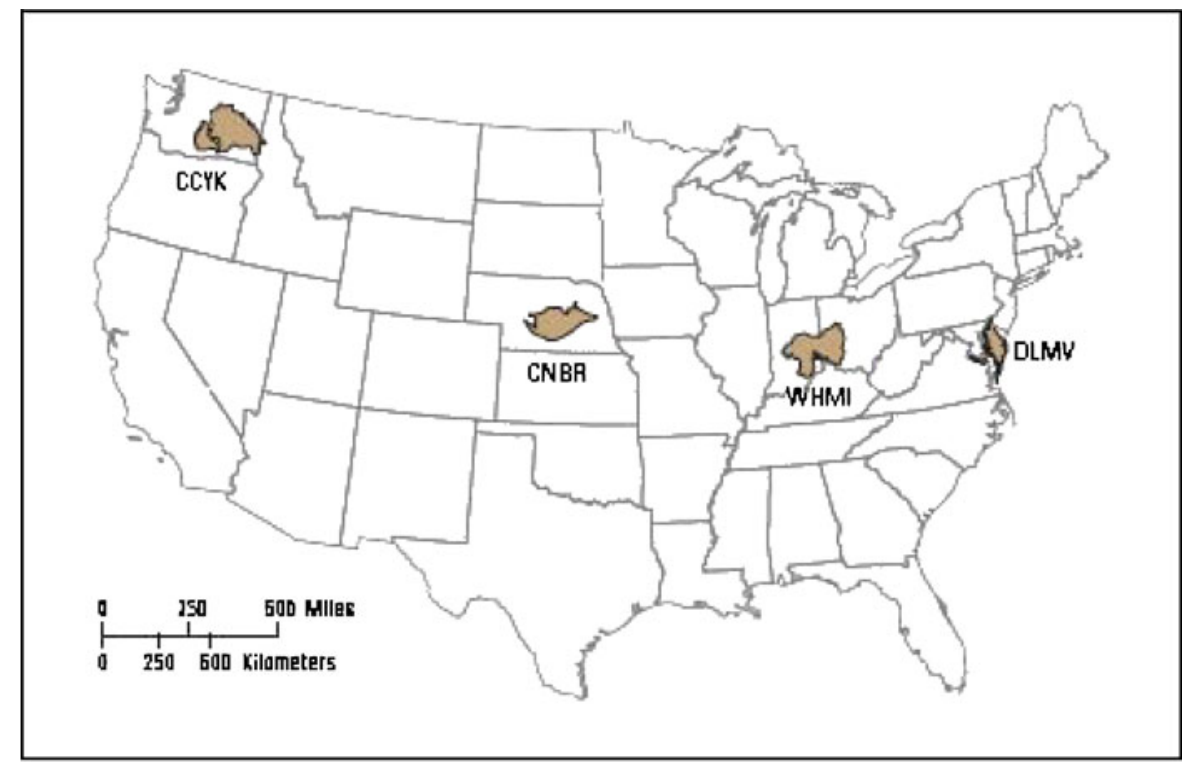

EXPLANATION

CCYK-Central Columbia Plateau-Yakima River Basin

CNBR-Central Nebraska Basins

DLMV-Delmarva Peninsula

WHMI-White, Great, and Little Miami River Basins ments that rely on irrigation practices. Agricultural land use varies from $11 \%$ to $80 \%$ of the drainage basin area (Table 1). Additional information on study areas and data can be accessed at http://wa.water.usgs.gov/neet/.
Site selection

Sites were selected within each study area to maximize the gradient of nutrient conditions while minimizing other natural or anthropogenic

Table 1 Summary of dominant study area features for the four study areas

\begin{tabular}{|c|c|c|c|c|}
\hline & $\begin{array}{l}\text { Central Columbia } \\
\text { Plateau-Yakima River } \\
\text { Basin (CCYK) }\end{array}$ & $\begin{array}{l}\text { Central Nebraska } \\
\text { Basins (CNBR) }\end{array}$ & $\begin{array}{l}\text { Delmarva } \\
\text { Peninsula } \\
(\text { DLMV) }\end{array}$ & $\begin{array}{l}\text { White-Miami } \\
\text { River Basins } \\
\text { (WHMI) }\end{array}$ \\
\hline Number of sites & 10 & 7 & 8 & 8 \\
\hline Climate & Arid plains and plateaus & Semi-humid plains & Humid plains & Semi-humid plains \\
\hline $\begin{array}{l}\text { Agricultural } \\
\text { commodities }\end{array}$ & $\begin{array}{l}\text { Wheat grains, alfalfa, } \\
\text { potatoes, vegetables }\end{array}$ & Corn, soybeans & $\begin{array}{l}\text { Corn, alfalfa, } \\
\text { soybeans, pasture }\end{array}$ & Corn, soybeans \\
\hline $\begin{array}{l}\text { USEPA level III } \\
\text { ecoregions }\end{array}$ & Columbia Plateau & Central Great Plains & Southeastern Plains & $\begin{array}{l}\text { Central Corn } \\
\text { Belt Plains }\end{array}$ \\
\hline $\begin{array}{l}\text { USEPA } \\
\text { nutrient ecoregions }\end{array}$ & Xeric West & $\begin{array}{l}\text { Central Cultivated } \\
\text { Great Plains }\end{array}$ & Eastern Coastal Plain & $\begin{array}{l}\text { Corn Belt and Northern } \\
\text { Great Plains }\end{array}$ \\
\hline Dominant land & Agriculture, 11 & Agriculture, 61 & Agriculture, 35 & Agriculture, 80 \\
\hline uses-median values & Pasture/grassland, 16 & Pasture/grassland, 35 & Forest, 31 & Pasture/grass, 16 \\
\hline within basin (\%) & Forest, 69 & Forest, 3 & Wetland, 15 & Forest, 4 \\
\hline
\end{tabular}

USEPA US Environmental Protection Agency 
factors. In order to select sites, basin and reach coverages were derived from 30-m digital elevation model data obtained from the USGS Elevation Derivatives for National Applications project. Wadeable stream sites were selected within each study area using geodata, predicted nutrient loads (Ruddy et al. 2006), and measured nutrient concentrations, habitat, and stream size. This resulted in 33 streams being selected across the four agricultural study areas.

\section{Data collection}

Water quality Two sets of water quality samples were collected at each site. A nutrient sample was collected ca 30 days prior to the metabolism study with samples analyzed for ammonia plus organic nitrogen, nitrate, nitrite, total nitrogen (TN), orthophosphate, and total phosphorus (TP) in milligrams per liter (Patton and Kryskalla 2003; Fishman 1993). The second sample was collected just prior to the metabolism measurements and was analyzed for nutrients plus dissolved organic carbon (Brenton and Arnett 1993), suspended sediment, and nitrogen, organic carbon, inorganic carbon, and total carbon in suspended sediment (US Environmental Protection Agency 1997). Turbidity was collected using a Hach 2100P portable turbidimeter. ${ }^{1}$ All water quality samples were analyzed by the USGS National Water-Quality Laboratory (NWQL; http://nwql.usgs.gov/pubs-all.shtml) at Lakewood, Colorado, with the exception of samples analyzed for suspended sediment concentrations, which were analyzed by the USGS Sediment Laboratory at Iowa City, Iowa.

Chlorophyll Sestonic and benthic chlorophyll samples were collected in each study reach following the collection of metabolism data. Sestonic algal samples were subsampled from a composite of surface water samples collected at equal-width

\footnotetext{
${ }^{1}$ Any use of trade, product, or firm names is for descriptive purposes only and does not imply endorsement by the US Government.
}

intervals across the stream. A 50-mL aliquot of the surface water sample was filtered through a 47-mm glass fiber filter (Moulton et al. 2002). The filtration step was repeated until a thin pigmented film was present on the filter. The sestonic algae filters were prepared under subdued lighting conditions, folded, and wrapped in aluminum foil to minimize chlorophyll degradation due to light exposure. The filters were frozen in the field and shipped on dry ice to the NWQL for analyses of chlorophyll $a(\mathrm{Chl} a)$ and pheophytin (Moulton et al. 2002) using EPA method 445.0 (Arar and Collins 1997a, b).

Composite benthic algal samples were collected from two targeted habitats in each study reach: a richest targeted habitat (RTH) and a fine-grained depositional targeted habitat (DTH). The RTH samples were collected from rocks in the CCYK and WHMI study areas and from woody snags in the CNBR and DLMV study areas. Within each stream, five individual RTH samples were collected from the targeted habitat (rock or wood), using a surface or cylinder scrape methodology (Moulton et al. 2002), and composited. The homogenized mixture was filtered in 5-mL increments until a thin pigmented film was present on the filter (Moulton et al. 2002). The DTH samples were processed using a modification of methods by Stevenson and Stoermer (1981). Five surficial fine-grain samples were collected from the reach using an inverted Petri plate and composited. Elutriation was used to separate the algae from the fine-grained material by adding $100 \mathrm{~mL}$ of drinking water to the sample, capping the sample container tightly, and inverting the container 15 times. The sample was permitted to sit for $5 \mathrm{~s}$, and then the algae-water mixture was poured into a clean 1-L plastic container, taking care not to introduce sand into the clean container. This process was repeated two more times. The homogenized mixture was filtered in 5- to $10-\mathrm{mL}$ increments until a thin pigmented film was present on the filter (Moulton et al. 2002). Similar to the sestonic chlorophyll samples, all RTH and DTH periphyton filters were prepared under subdued light, stored in the dark, frozen in the field, and shipped on dry ice to the NWQL for analyses of Chl $a$ and ash-free dry weight (AFDW) (Moulton et al. 2002). 
Reach-scale physical habitat Physical habitat was assessed at the stream reach scale (ca 100-150 m), which was defined as a repetition of a geomorphic sequence (e.g., two riffles and two pools) or 20 channel widths if repetitive units were not present within the reach (Fitzpatrick et al. 1998). A total of 11 equidistant transects oriented perpendicular to the longitudinal axis of the channel were established throughout the reach, with wetted channel width $(\mathrm{m})$ measured at each transect. Water depth $(\mathrm{cm})$, water velocity $(\mathrm{cm} / \mathrm{s})$, and percent substrate type (bedrock, boulder, cobble, gravel, sand, and silt) were measured at five points across each transect. A densiometer was used at each transect to measure percent canopy cover at midchannel. Reach gradient was determined from water-surface elevations measured with a surveyor's level. Additional field measurements included stream discharge $\left(\mathrm{m}^{3} / \mathrm{s}\right)$ and water temperature $\left({ }^{\circ} \mathrm{C}\right)$. Canopy openness was measured using a solar pathfinder (see footnote 1) at midchannel in five of the 11 habitat transects and converted to solar energy in millijoules per square meter per day (Solar Pathfinder ${ }^{\odot}$ 2002). The average percent cover of filamentous algae and submerged macrophytes was determined using a modification of the method by Biggs and Kilroy (2000). Coverage of macroalgae and macrophytes greater than $3 \mathrm{~cm}$ in length was measured within a $0.09-\mathrm{m}^{2}$ quadrat at five points along each of the 11 transects, and the measurements averaged to generate a reach-level value. Estimates of percent riparian land cover for all study sites were determined at buffer widths of $25,50,100,150$, and $250 \mathrm{~m}$ at the reach and segment scale using methods outlined in Johnson and Zelt (2005).

Site-specific estimates of precipitation and temperature were determined by compiling monthly values for the National Oceanic and Atmospheric Administration (NOAA) weather stations nearest the stream sites during the year the metabolism study was conducted (National Oceanic and Atmospheric Administration 2008). Samplingperiod mean precipitation and temperature values were computed for each site using values for the month of, and the month prior to, the sampling effort. For example, if sampling at a site occurred during April and May 2003, the monthly precipitation and temperature values from the nearest
NOAA weather station for April and May 2003 were averaged to produce a sampling-period mean value.

Basin-scale measures Basin-scale geographic measures were compiled using a geographic information system (GIS), for geology, nutrient loading, and various hydrologic parameters and released in the report by Brightbill and Munn (2008). All raster processing used 30-m spatial resolution, and all GIS analysis was completed using Arc Info Workstation, Environmental Systems Research Institute, Redlands, California.

Drainage area was determined from digital maps at either 1:24,000 or 1:250,000-scale, depending on the size of the watershed. Land cover and geology were characterized by component percentage of the drainage basin. The source for land-cover information was an enhanced version (Nakagaki and Wolock 2005) of the USGS National Land Cover Data 1992 (US Geological Survey 1999; Vogelmann et al. 2001). Satelliteimagery-based land-cover data (30-m resolution) were used to compile watershed percentages by land classification as well as the percentages for riparian zones buffered to approximately $90 \mathrm{~m}$ from the stream centerline. The national data sets of land cover (US Geological Survey 1999), bedrock geology (King and Beikman 1974a, b; Schruben et al. 1998), and surficial geology (Hunt 1979; Clawges and Price 1999) were all gridded at 30-m resolution then overlain with the basin boundaries to determine the area and percentage of each classification in each watershed. The 1:100,000scale National Hydrography Dataset Plus (NHDPlus) was used to derive values for stream density, stream order, and the percent of canals and ditches within the basin boundaries of each site. The NHDPlus integrates the NHD with the National Elevation Dataset and the Watershed Boundary Dataset for an enhanced NHD stream network with improved names, value-added attributes (US Geological Survey and U. S. Environmental Protection Agency 2003). Parts of the attributes for every stream are the Strahler order and a code indicating stream type (StreamRiver (natural), Canal, Ditch, and Pipeline). These values were used to calculate the percentage of each stream type within the drainage area. 
Stream metabolism measurements Stream metabolism was done using the two-station open-water technique (Marzolf et al. 1994), with water temperature, DO concentration, $\mathrm{pH}$, and specific conductance measured continuously for a period of at least $48 \mathrm{~h}$ using YSI ${ }^{\circledR}$ 600XLM sondes (see footnote 1) (YSI Incorporated 2002). The recording interval was no greater than $5 \mathrm{~min}$ and was always less than the travel time through the reach. Barometric pressure was measured at the time the sondes were deployed and recovered. Sonde calibration and data processing were done according to the methods of Wagner et al. (2006).

Photosynthetically active radiation (PAR) was measured in micromoles continuously during the time water-quality sondes were deployed. A $\mathrm{HOBO}^{\circledR}$ PAR smart sensor attached to a $\mathrm{HOBO}^{\circledR}$ microstation (see footnote 1) (unpublished manual, Onset Corporation) measured PAR once per minute and recorded an average reading every $15 \mathrm{~min}$. The light meter was placed on the stream bank between the upstream and downstream sondes at a location representative of the general light/riparian conditions for the reach.

Travel time within the study reach on the day the water-quality sondes were deployed was measured using Rhodamine dye slug injections (Kilpatrick and Wilson 1989). The travel time was used to establish the measurement interval (less than the travel time) for the YSI Sonde and for the stream metabolism calculations described below.

\section{Stream metabolism calculations}

Reaeration estimate An estimate of the reaeration rate coefficient $\left(K_{2}\right)$ is required to estimate stream metabolism, and although the direct measurement using a tracer gas (Kilpatrick et al. 1989 ) is the preferred method for determining site-specific values of $K_{2}$, the large number of sites in this study precluded application of the tracer-gas method. In the absence of tracer gas data, $K_{2}$ values were estimated using available empirical relations. Thirty distinct empirical equations for the prediction of $K_{2}$ were identified from the literature. Application of the equations was supplemented by use of a USGS database containing information from $K_{2}$ measurements made using the tracer-gas method at 493 individual sites, some with multiple measurements under varying flow conditions (Melching and Flores 1999). The equations and $K_{2}$ database were used with the site-specific measurements of discharge, reachaverage stream velocity, depth, width, and stream slope to estimate $K_{2}$, as follows:

1. The USGS $K_{2}$ database was searched to identify sites having hydraulic characteristics (primarily slope, velocity, and depth) similar to the study site.

2. $K_{2}$ was estimated for the selected USGS database sites (usually about two to four sites) using each of the 30 empirical relations.

3. Predicted $K_{2}$ values were compared to measured values in the database. The one to three empirical relations that were the best predictors of the measured $K_{2}$ values for the subset of USGS database sites were identified.

4. The selected empirical equations were applied to the metabolism study sites to estimate $K_{2}$; in the cases where more than one predictive equation was used, an average of the results was applied to the metabolism site.

Metabolism calculations Metabolism is routinely calculated from in situ data, although there is no standard set of procedures. Consequently, as part of this study, we (1) standardized the calculations of stream metabolism and (2) developed an automated procedure for performing and archiving the calculations for a large number of sites. The Stream Metabolism Program was developed to automate and archive stream metabolism calculations; each calculation and assumption within the program has been documented by Bales and Nardi (2007) and is based completely on standard methods (Odum 1956; Marzolf et al. 1994; Mulholland et al. 2001).

The Stream Metabolism Program imports in situ DO, water temperature, and PAR time series data and adjusts the readings such that time intervals are consistent. Temperature and DO readings are corrected for instrument fouling and drift based on pre- and postdeployment instrument calibrations (Wagner et al. 2006). DO saturation concentration is calculated at each time interval from DO concentration, water temperature, and barometric pressure data. Additional site-specific 
data, such as depth, wetted area, stream slope, travel time, reaeration rate, and discharge were input through the program interface.

The 24-h calculation period for the metabolic rates is automatically selected based on the PAR data, with the GPP calculation for the daylight period beginning and ending when PAR exceeds, then returns to, background levels. The 24-h community respiration estimate utilized for this study is based on a procedure described by Mulholland et al. (2001) in which the daytime respiration is determined by extrapolating between the net oxygen exchange rate during the 1-h predawn and postdusk periods. While respiration is calculated as a negative number in the metabolism program, it is reported as a positive value in the paper for the sake of convenience and to report the data in a manner that is comparable with other studies (Hall 1972; Bott et al. 1985, 2006; Wiley et al. 1990; McTammany et al. 2007; Mulholland et al. 1997, 2001; Houser and Mulholland 2005). The net ecosystem production is the difference between the GPP and CR-24 values. Gross photosynthetic efficiency (GPPe), which is the ratio of GPP to PAR (Bott et al. 1985), was calculated to normalize the amount of oxygen produced during photosynthesis for light availability, allowing for comparisons of data collected from sites across a broad geographical area under varying light conditions.

\section{Statistical analysis}

The combination of measured and derived stream habitat and riparian data resulted in 110 environmental variables, with some redundant and therefore correlated variables. The number of variables was reduced prior to regression analysis using a combination of principal component analysis (PCA) (Clarke and Gorley 2006) and Spearman rank correlations (Lam 2001). The dataset was initially subdivided into four categories: geomorphic (e.g., slope), hydraulic (e.g., depth), substrate (e.g., percent fines), and cover (e.g., canopy). PCAs were performed on each of the four datasets, and individual variables with the highest loading on each of the first three PC axes were selected. This procedure resulted in a reduction of the number of environmental vari- ables from 110 to 25 . The remaining 25 environmental variables (including canopy and riparian cover, solar radiation, stream width, depth, slope, velocity, and substrate) were combined with the nearly 100 measures of chemical concentrations (other than nitrogen and phosphorus), physical properties measurements (e.g., $\mathrm{pH}$, specific conductance, water temperature), and selected basinscale variables.

Spearman correlations (rho) were used to identify relations between metabolism variables and nearly 125 independent measures. Physical, water-chemistry, and basin-scale variables that had a Spearman correlation coefficient (rho) greater than 0.5 with any metabolism variables were included in the regression models. Prior to stepwise regression analyses, all data were logtransformed, taking the natural log of all values, except data reported as a proportion or percentage, which were square-root transformed. For the purpose of statistical analyses, nutrient values less than the detection limit were set at one half the method detection level. The values for both nutrient sampling events at a site were averaged to generate a single set of values for subsequent analysis and summarized by study area.

\section{Results}

Nutrients and chlorophyll

TN concentrations ranged from $0.19 \mathrm{mg} / \mathrm{L}$ (CCYK) to $8.98 \mathrm{mg} / \mathrm{L}$ (CNBR) for streams in this study (Table 2). WHMI and CNBR had the highest median concentrations of TN (4.01 and $4.03 \mathrm{mg} / \mathrm{L}$, respectively) followed by DLMV (2.56 mg/L) and CCYK (1.28 mg/L) (Table 2, Fig. 2). TP concentrations ranged from $0.01 \mathrm{mg} / \mathrm{L}$ (DLMV) to $1.71 \mathrm{mg} / \mathrm{L}$ (CNBR) for the study streams (Table 2). CNBR had a significantly higher median TP concentration $(0.72 \mathrm{mg} / \mathrm{L})$ than CCYK (0.12 mg/L), WHMI $(0.11 \mathrm{mg} / \mathrm{L})$, or DLMV (0.08 mg/L) (Table 2, Fig. 2).

RTH Chl $a$ ranged from 2.6 to $615 \mathrm{mg} / \mathrm{m}^{2}$ with the highest value and the largest range observed at the DLMV sites (23 to $615 \mathrm{mg} / \mathrm{m}^{2}$ ) (Table 2). Chlorophyll $a$ in depositional areas (DTH Chl $a$ ) were lower than RTH Chl $a$ values in all study 


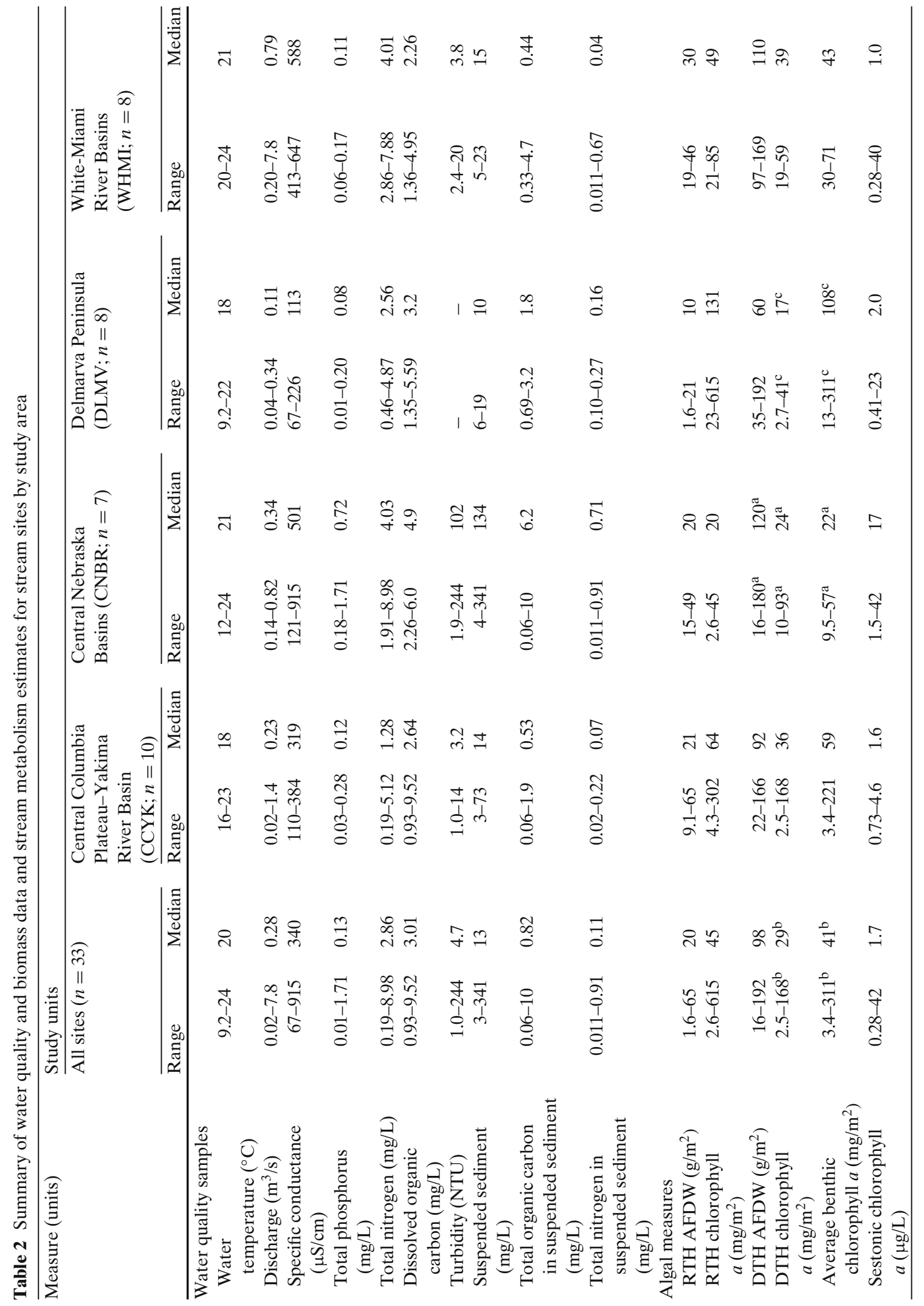




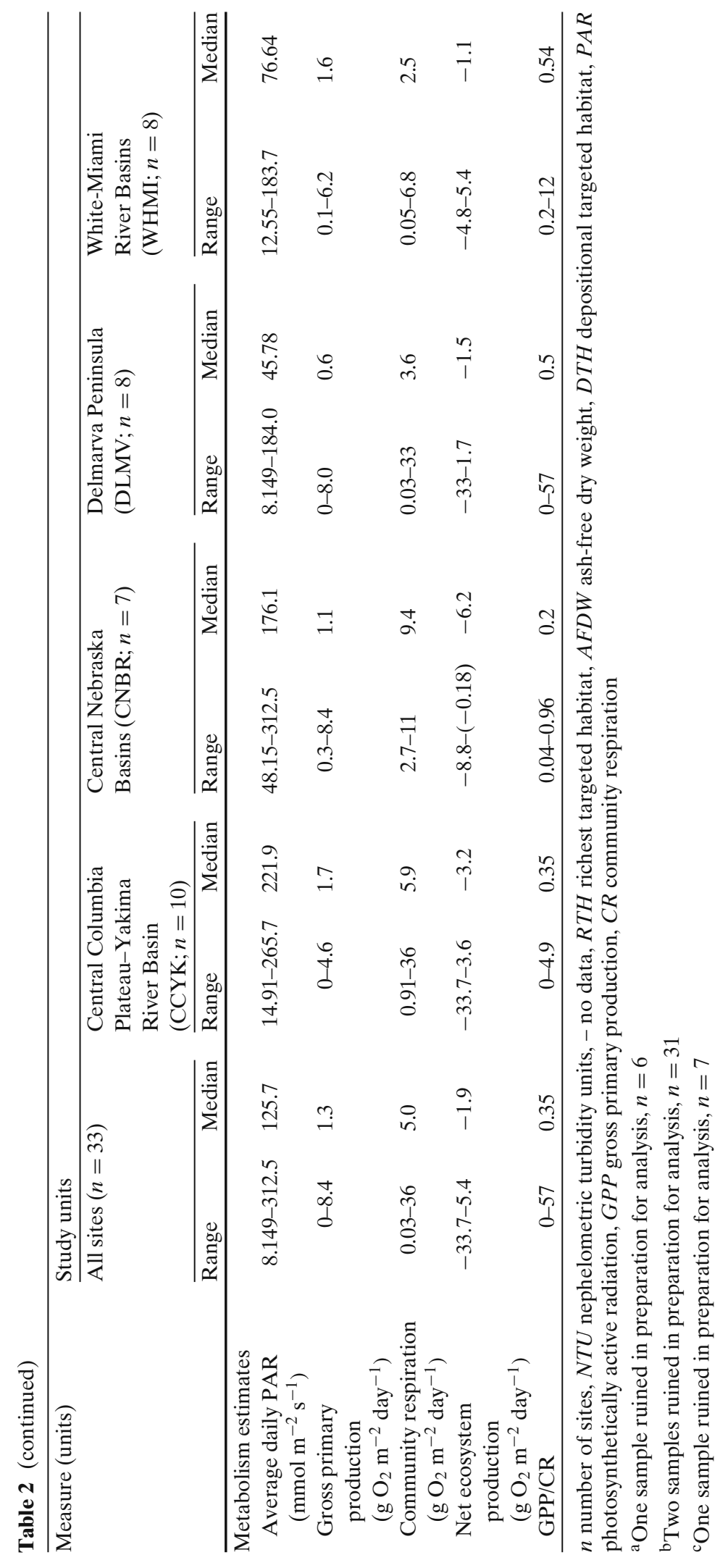




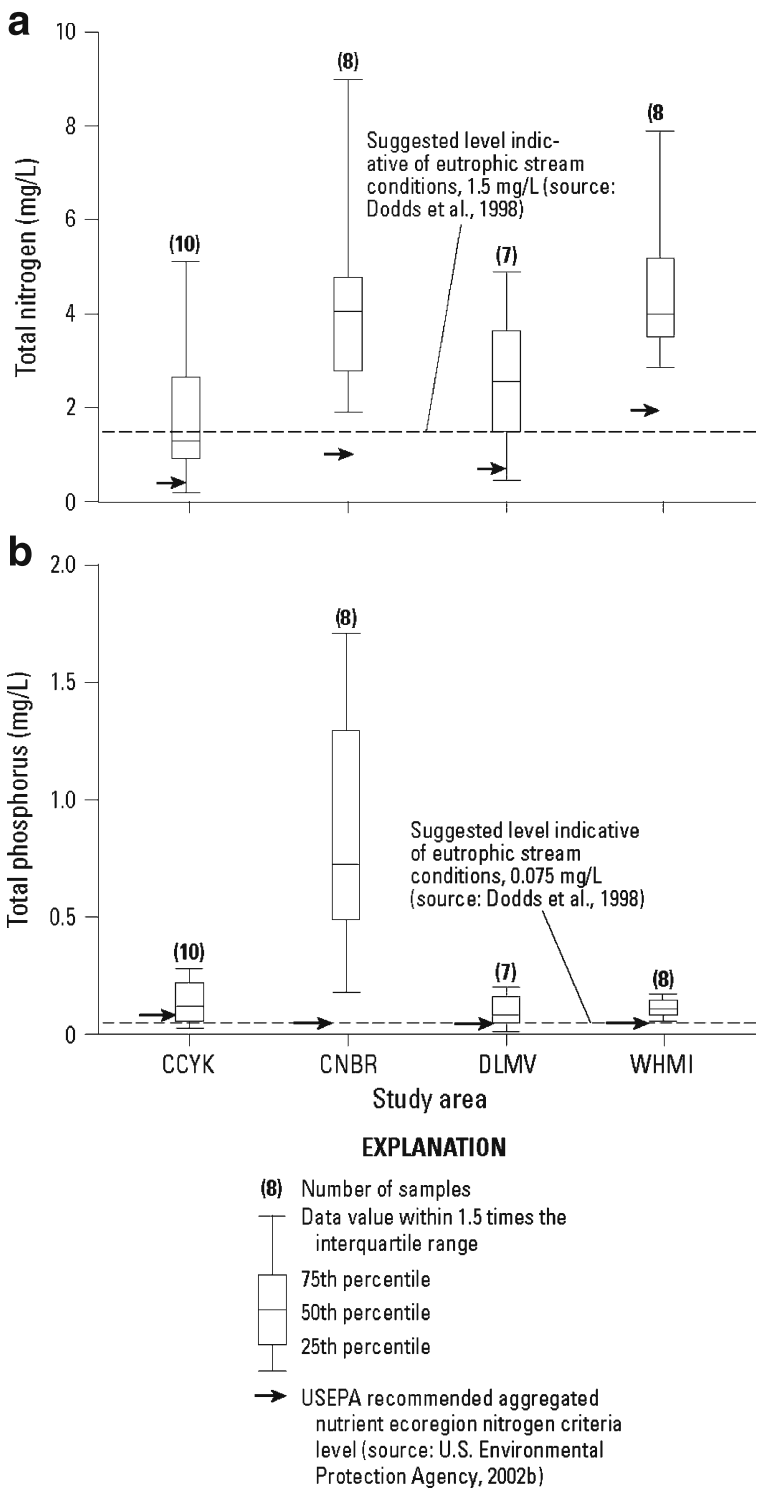

Fig. 2 Box plots showing a distribution of total nitrogen by study area, $\mathbf{b}$ distribution of total phosphorus by study area

areas except the CNBR, where the median RTH Chl $a$ value was $20 \mathrm{mg} / \mathrm{m}^{2}$, and the median DTH Chl $a$ was $24 \mathrm{mg} / \mathrm{m}^{2}$. The measurement of average benthic Chl $a$ (average of the RTH Chl $a$ and DTH Chl $a$ measurements) ranged from 3.4 to $311 \mathrm{mg} / \mathrm{m}^{2}$ with the highest value again in the DLMV study area (Table 2). Sestonic Chl $a$ concentrations ranged from 0.28 to $42 \mu \mathrm{g} / \mathrm{L}$, with the highest concentration and the largest range in concentrations in the CNBR study area (1.5 to $42 \mu \mathrm{g} / \mathrm{L})$ (Table 2).

\section{Reach- and basin-scale measures}

Basin size of streams sampled in the study areas ranged from 7.2 to $786 \mathrm{~km}^{2}$ (Table 3). The variability in basin size largely reflects geographic location and climate of the study areas. In the arid to semi-arid study areas in the western USA (CCYK and CNBR), the drainage basin size was generally larger than in the humid east (DLMV and WHMI), yet there was little difference in median channel width and stream depth between the western and eastern streams (Table 3). Median stream velocity was greatest in CCYK, as may be expected given that stream gradient also was larger than in the other study areas (Table 3 ).

The largest differences in median values among the study areas were in percent canopy cover, habitat cover (Table 3), and land use (Table 1). Canopy cover, a component of riparian habitat, is an important factor in influencing stream systems and varied greatly across the study areas. Western study sites (CCYK and CNBR) generally had more open canopies with median canopy cover of $22 \%$ and $43 \%$, respectively, whereas the median canopy covers were $56 \%$ and $71 \%$ for the DLMV and WHMI study areas, respectively (Table 3). Conversely, the percentage of instream habitat cover (such as woody debris or overhanging vegetation) was more extensive in the western study areas than in the east. Although all study areas were located in areas influenced by agricultural land use, there were some distinct differences in percentage of land used for agriculture among the study areas. The extent of agricultural lands within the basins (cropland and pasture) varied from a median $27 \%$ in the CCYK to a median $96 \%$ in both the CNBR and WHMI (Table 1).

Metabolism

Overall, GPP ranged from zero to $8.4 \mathrm{~g} \mathrm{O}_{2} \mathrm{~m}^{-2}$ day $^{-1}$, with the highest values in the CNBR and DLMV study areas (8.4 and $8.0 \mathrm{~g} \mathrm{O}_{2} \mathrm{~m}^{-2}$ day $^{-1}$, respectively) (Table 2, Fig. 3). Median values of GPP were similar among study areas, other than DLMV, for which the median GPP was one half 


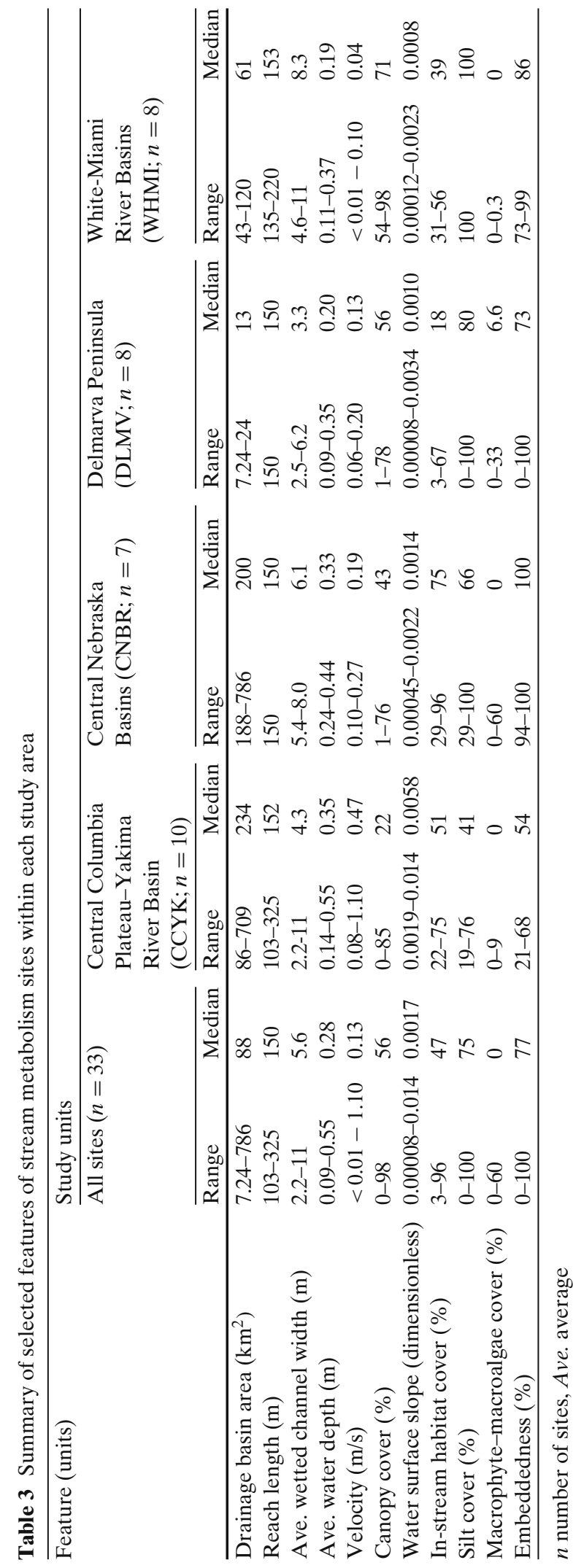


Fig. 3 Plots showing the range in gross primary production, 24-h community respiration, and net ecosystem production within the Central Columbia Plateau-Yakima River Basin $(C C Y K)$, Central Nebraska Basins $(C N B R)$, Delmarva Peninsula $(D L M V)$, and White-Miami River Basins (WHMI) study areas

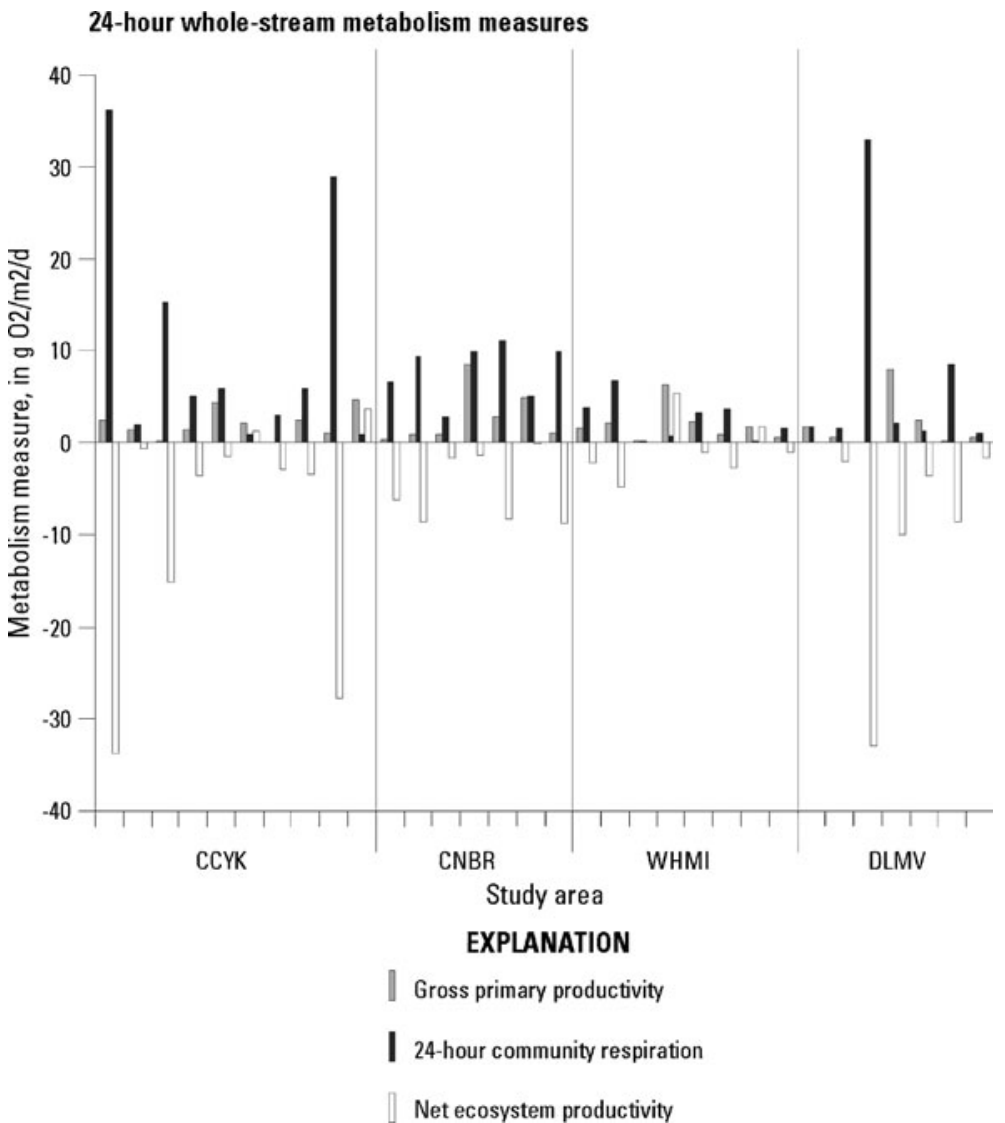

the median or less of the other study areas. Rates of CR-24 ranged from $0.03 \mathrm{~g} \mathrm{O}_{2} \mathrm{~m}^{-2}$ day $^{-1}$ to $36 \mathrm{~g} \mathrm{O}_{2} \mathrm{~m}^{-2}$ day $^{-1}$ (Table 2, Fig. 3), with the highest value for CR-24 found in the CCYK study area. NEP estimates were negative, and $P / R$ (GPP:CR-24) ratios were less than one for 27 of the 33 sites indicating heterotrophic conditions (Fig. 3). The $P / R$ ratios were less than or equal to 0.25 , indicating strongly heterotrophic conditions, at more than one third of the sites at the time of sampling.

\section{Statistical analysis}

There were no statistically significant relations between GPP or CR-24 and any of the independent variables when data for all study areas were combined; however, significant regression models were developed for GPP, GPPe, and CR-24 (Table 4) for individual study areas. In regards to GPP, significant regression models were de- veloped for CNBR, DLMV, and WHMI with $r^{2}$ values ranging from 0.79 for WHMI to 0.91 for the CNBR (Table 4). GPP in the CNBR were negatively influenced by suspended sediment and average velocity measurements (Table 4), although upon reviewing the Spearman correlation matrix, the two explanatory variables are weakly correlated with a correlation coefficient of rho $=0.51$. Similarly, the analytical results indicated negative relations between GPP and drainage basin area within the WHMI $\left(r^{2}=0.79, p=0.003\right)$, which may reflect overall intensity of agricultural activities in these study areas and between GPP and the percent of canopy closure in the DLMV $\left(r^{2}=0.83\right.$, $p=0.005)$.

GPPe, which is GPP corrected to solar radiation, were related to some measures of nutrients, algae, and habitat (Table 4). Percent instream cover was negatively related to GPPe in the CCYK $\left(r^{2}=0.42, p=0.005\right)$, indicating the effect of instream shading on primary production. GPPe 
Table 4 Regression results for stream metabolism sites within each study area

\begin{tabular}{|c|c|c|c|c|c|c|}
\hline Study area & Response variable & Intercept & Predictive variable & $\begin{array}{l}\text { Number of } \\
\text { samples }\end{array}$ & $\mathrm{r}^{2}$ & p-value \\
\hline \multirow[t]{3}{*}{ All } & GPP & NA & None & 33 & NA & NA \\
\hline & CR-24 & NA & None & 33 & NA & NA \\
\hline & GPPe & NA & None & 33 & NA & NA \\
\hline \multirow[t]{3}{*}{ CCYK } & GPP & NA & None & 10 & NA & NA \\
\hline & CR-24 & -2.91 & $\begin{array}{l}1.21(\text { RTH AFDW })^{\mathrm{a}} \\
+0.26{\text { (percent canal } / \text { ditches })^{\mathrm{b}}}^{\text {percent }}\end{array}$ & 10 & 0.76 & 0.007 \\
\hline & GPPe & 3.29 & $\begin{array}{l}-0.37 \text { (percent instream } \\
\text { habitat cover) }^{\mathrm{b}}\end{array}$ & 10 & 0.42 & 0.043 \\
\hline \multirow[t]{3}{*}{ CNBR } & GPP & -1.26 & $\begin{array}{l}-0.29{\text { (suspended sediment })^{\mathrm{a}}}+(-1.70)(\text { average velocity })^{\mathrm{a}}\end{array}$ & 7 & 0.91 & 0.008 \\
\hline & CR-24 & 0.072 & 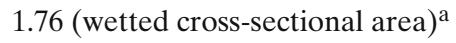 & 7 & 0.80 & 0.007 \\
\hline & GPPe & 0.15 & -0.415 (orthophosphate) $^{\mathrm{a}}$ & 7 & 0.85 & 0.003 \\
\hline \multirow[t]{3}{*}{ DLMV } & GPP & 2.24 & 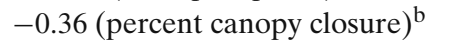 & 8 & 0.83 & 0.005 \\
\hline & CR-24 & 36.97 & 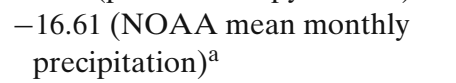 & 8 & 0.77 & 0.022 \\
\hline & GPPe & 2.17 & $-0.57(\mathrm{RTH} \text { AFDW) })^{\mathrm{a}}$ & 8 & 0.62 & 0.020 \\
\hline \multirow[t]{3}{*}{ WHMI } & GPP & 15.33 & $-3.66(\text { drainage area })^{\mathrm{a}}$ & 8 & 0.79 & 0.003 \\
\hline & CR-24 & NA & None & 8 & NA & NA \\
\hline & GPPe & 12.38 & 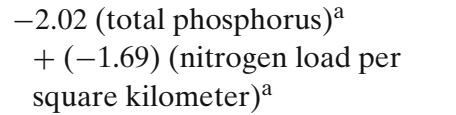 & 8 & 0.77 & 0.02 \\
\hline
\end{tabular}

a All data have been transformed by taking the natural log of the original value

${ }^{b}$ All data have been transformed by taking the square root of the original value

in the DLMV was most strongly related to RTH AFDW $\left(r^{2}=0.62, p=0.02\right)$. In the CNBR and WHMI, nutrients (orthophosphate for the CNBR) (Table 4, $r^{2}=0.85, p=0.003$ ) and TP and area-weighted nitrogen loading (the estimated load of nitrogen to the basin from fertilizer, manure, and atmospheric deposition) for the WHMI $\left(r^{2}=.77, p=0.02\right)$ explained a significant amount of the variance in GPPe; however, the relations between GPPe and nutrients in these areas were negative.

Three study areas (CCYK, CNBR, and DLMV) yielded models that explained a significant amount of the variance in estimates of CR-24 (Table 4). The percentage of ditches and canals in each stream basin, in combination with RTH AFDW, explained $76 \%$ of the variance in CCYK CR-24 $(p=0.007)$ (Table 4). The wetted cross-sectional area (wetted width times depth) was related to estimates of CR-24 in the CNBR (Table 4). The NOAA mean monthly precipitation was the best predictor for CR-24 in the DLMV study area $\left(r^{2}=0.77\right)$ (Table 4$)$.
Other variables that were included in Spearman rank correlations and selected regression analyses and not found to be related to GPP, CR-24, or GPPe measurements include: stream gradient, channel substrate, percent macrophyte cover; measurements of dissolved as well as particulate carbon; particulate nitrogen; total and daily average PAR; phosphorus loading to the basin; and various measures of land use (for agriculture, pasture, forest, residential, grassland, and wetland) within the riparian zone, as well as within the stream basins.

\section{Discussion}

Nutrient and algal measures as related to stream metabolism in agricultural areas

The primary objective of this study was to examine the relative influence of nutrients (nitrogen and phosphorus) and habitat on stream metabolism in four agricultural areas. GPP rates 
in this study ( 0 to $8.4 \mathrm{~g} \mathrm{O}_{2} \mathrm{~m}^{-2}$ day $^{-1}$ ) were comparable to rates measured in other streams having varying levels of basin disturbance (Hall 1972; Bott et al. 1985; Young and Huryn 1996; Mulholland et al. 2001; Uehlinger and Brock 2005) and below some of the values reported for similar prairie/agriculture land use $(<0.1$ to $>50 \mathrm{~g} \mathrm{O}_{2} \mathrm{~m}^{-2}$ day $^{-1}$, Wiley et al. 1990). CR-24 rates generally were greater than those measured in investigations by Hall (1972), Hall and Tank (2003), and Mulholland et al. (2001), which ranged from 0.4 to $13 \mathrm{~g} \mathrm{O}_{2} \mathrm{~m}^{-2}$ day $^{-1}$ but were comparable to, and in some cases lower than, rates reported in the literature for similarly disturbed systems (Wiley et al. 1990; Houser and Mulholland 2005). The mean respiration rate for all of our sites was $7.4 \mathrm{~g} \mathrm{O}_{2} \mathrm{~m}^{-2}$ day $^{-1}$, and the median value was $4.4 \mathrm{~g} \mathrm{O}_{2} \mathrm{~m}^{-2}$ day $^{-1}$, both of which also are well within the range of previously reported values.

There were no strong relations between GPP, GPPe, or CR-24 and any of the independent variables for the combined data set. Two relations existed between algal biomass and stream metabolism for individual study areas (CR-24 and RTH AFDW for CCYK and GPPe and RTH AFDW for DLMV). Relations between metabolism measures and nutrient concentrations for individual study areas were limited. We found that correcting GPP values for available light resulted in negative statistical relations between GPPe and orthophosphate in the CNBR and between GPPe and TP and area-weighted nitrogen loading in the WHMI.

Although it was expected that production increases with increasing nutrient levels, GPPe in CNBR and WHMI were negatively related to phosphorus levels, and in the CNBR, GPP was negatively related to suspended sediment. These negative relations may be explained by the strong correlation between phosphorus and suspended sediment concentrations, potentially reducing the amount of light available for primary production.

Ash-free dry weight was related to selected metabolism measures, while none of the chlorophyll values (benthic or sestonic) were related. AFDW measures include all organic matter, live or dead, and often are a measure of detritus rather than algal biomass. As such, the positive relation between RTH AFDW and CR-24 in the CCYK may indicate that a large part of the biomass measured is from sources other than algae, e.g., detrital material. Similarly, the negative relation between AFDW, as measured from woody snags, and GPPe in the DLMV study area indicates that the biomass measured is from sources other than oxygen-producing algae.

Selected environmental variables related to stream metabolism in agricultural systems

Past research has shown that physical factors, such as light availability, temperature, and channel/habitat characteristics (Bott et al. 1985, 2006; Wiley et al. 1990; Ortiz-Zayas et al. 2005; Uehlinger and Brock 2005), can significantly influence production and respiration.

Light availability Despite the availability of several measures of canopy coverage (percentage closed canopy, solar pathfinder measurements, estimates of riparian landuse/land cover for multiple buffer widths), the only measure of riparian cover that was associated with primary production in our study was the percent canopy closure in the DLMV streams, for which GPP decreased with an increase in canopy closure. A $t$ test comparing GPP for all sites in open canopy ( $<50 \%$ canopy) and closed canopy ( $>50 \%$ ) streams indicated that GPP was significantly higher $(p<0.05)$ in open streams $(\mathrm{GPP}=3.0)$ than closed streams $(\mathrm{GPP}=$ 1.4). GPP did not exceed $2.0 \mathrm{~g} \mathrm{O}_{2} \mathrm{~m}^{-2} \mathrm{day}^{-1}$ when the canopy closure was $>50 \%$ in the DLMV streams. Although the DLMV results support findings from other work in which riparian canopy cover was a predictor of stream ecosystem processes (e.g., GPP and CR-24) in some forested streams systems (Bunn et al. 1999; Mosisch et al. 2001), the measures of canopy cover and riparian vegetation were not related to production in our other study areas. It was expected that with the low percentage of canopy cover, many of the sites in CNBR and CCYK would be dominated by autotrophic processes. However, none of the sites in CNBR and just two of the sites in CCYK were GPP-dominated. In addition, the median percent of riparian woody vegetation for the WHMI sites was $85 \%$, which is similar to the $96 \%$ median 
value for CNBR, and median canopy openness for the WHMI sites $\left(4 \mathrm{~mJ} / \mathrm{m}^{2} /\right.$ day) was nearly half that for the DLMV sites $\left(7 \mathrm{~mJ} / \mathrm{m}^{2} /\right.$ day $)$. Nevertheless, there was no relation between light availability and metabolism metrics for this study area.

The negative relations of phosphorus and suspended sediment to production in the CNBR and WHMI may indicate that light is still a controlling factor, but light limitation is occurring instream rather than limitation because of canopy shading. Median turbidity (102 NTU) and suspended sediment $(134 \mathrm{mg} / \mathrm{L})$ values in the CNBR were significantly higher than in the other areas of the study, and previous studies (Wiley et al. 1990; Young and Huryn 1996) documented that turbidity or light attenuation (measured as depth times turbidity) were similarly negatively correlated with rates of GPP. While mean summertime turbidity values in Wiley et al. (1990), ranging from 2.43 to $100.8 \mathrm{NTU}$, were higher than those described in Young and Huryn (1996), the values were comparable to those measured in this study (combined dataset range of 1.0 to 244 NTU, CNBR range of 1.9 to 244 NTU) and were found, in combination with shading, to explain most of the variation in production. Other studies have described similar results with limited production rates in agriculturally influenced streams despite high nutrient concentrations and reduced shading from riparian cover (McTammany et al. 2007).

Channel or habitat characteristics The size of streams in this study as determined by the median values for average wetted width and depth at the time of sampling was relatively consistent among sites (Table 3). Despite the selection of relatively small streams (median wetted width of $5.6 \mathrm{~m}$ and median depth of $0.28 \mathrm{~m}$ ) for this study, all but five sites were dominated by heterotrophic processes. Wiley et al. (1990), however, found that the headwaters of streams with a more open canopy structure (as are typically present in agricultural systems, particularly in the arid west) tend to be dominated by autotrophic processes, although Bott et al. (1985) suggested that stream size alone cannot be used to classify metabolic status. While an overall longitudinal trend from heterotrophy to autotrophy occurred at all sites studied by Bott et al. (1985), the transition from annual heterotrophic to autotrophic status occurred at different downstream stations and was influenced by site-specific factors in addition to stream size.

The percentage of canals and ditches in the system was positively correlated with respiration rates in the CCYK study area. Canals and ditches were present in nine of the ten CCYK study basins, whereas canals and ditching were not present in the DLMV and were present in only four of the seven CNBR basins and two of eight WHMI study basins. The percentage canals/ditches in CCYK also was correlated to discharge $(\mathrm{rho}=0.86)$ and point velocity measurements $($ rho $=0.70)$, indicating an increase in flow with increased ditching and channel modification, likely because of irrigation return flows. Previous work has suggested that streams with velocity perturbations and unstable sediment were dominated by respiration (Young and Huryn 1996; Uehlinger and Naegeli 1998; Biggs et al. 1999), which is consistent with CCYK results. The models indicated that the wetted cross-sectional area in streams in CNBR explained most of the variability in CR-24 values in that area, with increased CR-24 values in streams with a larger cross-sectional wetted area.

Nutrients and biomass in agricultural areas

Although there was a broad range in TN (0.19$8.98 \mathrm{mg} / \mathrm{L})$ and TP (0.01-1.71 mg/L) concentrations at our sites, most concentrations measured exceeded the US Environmental Protection Agency (2002b) recommended nutrient criteria for the respective ecoregions (Table 5). For these four study areas, TN exceeded the proposed regional criteria at 88\% (DLMV), 90\% (CCYK), and $100 \%$ (CNBR and WHMI) of sites assessed in this study, whereas TP exceeded the proposed regional criteria at $75 \%$ of the sites in the DLMV and WHMI and $100 \%$ of the sites in the CCYK and CNBR. Therefore, based upon the proposed EPA criteria, concentrations of both TN and TP indicate that these four study areas have been substantially enriched by agricultural activities. While there are no recommended benthic algal biomass criteria at this time, Welch et al. (1998) reported that benthic algal $\mathrm{Chl} a$ values above $100 \mathrm{mg} / \mathrm{m}^{2}$ are considered potentially excessive. 
Table 5 The US Environmental Protection Agency's recommended criteria for nutrients and algal biomass for aggregated nutrient ecoregions included in this study

\begin{tabular}{lllll}
\hline Measure (units) & \multicolumn{4}{l}{ Study unit and aggregated nutrient ecoregion (ecoregion number) } \\
\cline { 2 - 5 } & Central Columbia & Central Nebraska & Delmarva & White-Miami River \\
& $\begin{array}{l}\text { Plateau-Yakima } \\
\text { River Basin: }\end{array}$ & Basins: South & Peninsula: & Basins: Corn belt \\
& Xeric west (III) & Great Plains (V) & plains (XIV) & and northern \\
& 0.38 & 0.88 & 0.71 & 2.18 \\
\hline Total nitrogen $(\mathrm{mg} / \mathrm{L})$ & 0.021 & 0.067 & 0.031 & 0.076 \\
Total phosphorus $\left(\mathrm{mg} / \mathrm{L}^{\mathrm{a}}\right)$ & 3.00 & $3.75^{\mathrm{b}}$ & 2.70 \\
Chlorophyll $a(\mu \mathrm{g} / \mathrm{L}$ based on & 1.78 & & & 6.36 \\
fluorometric measurement & & 7.83 & 3.04 & \\
Turbidity (FTU) & $2.34^{\mathrm{c}}$ & & & \\
\hline
\end{tabular}

Source: US Environmental Protection Agency, 2002b

FTU, formazin turbidity unit; $N T U$, nephelometric turbidity unit

${ }^{a}$ Converted from micrograms per liter for consistency with text

${ }^{\mathrm{b}}$ Spectrophometric measurement

${ }^{\mathrm{c}} \mathrm{NTU}$, turbidity unit of measurement

Average benthic Chl $a$ in our study ranged from 3.4 to $311 \mathrm{mg} / \mathrm{m}^{2}$, with six of the 31 sites having values greater than $100 \mathrm{mg} / \mathrm{m}^{2}$.

Similarly, measurements of sestonic Chl $a$ were not indicative of an enriched trophic condition implied by the nutrient concentrations, as $73 \%$ of the streams would be classified as oligotrophic with sestonic Chl $a$ concentrations less than $10 \mu \mathrm{g} / \mathrm{L}$ (Dodds et al. 2006).

These results suggest that chlorophyll concentrations may not always be good indicators of nutrient enrichment in agricultural streams. Rather, algal biomass appears to be controlled by basin conditions and/or physical alteration to the stream, as discussed below. Our findings are consistent with other studies in agricultural systems that suggest factors, such as drainage alterations, other than solely increased nutrient concentrations influence algal biomass (Wiley et al. 1990; Royer et al. 2004).

\section{Management implications: nutrient transport to} downstream receiving water

Few of the streams in our study were autotrophic, and most had low potential for nutrient uptake through primary production. This finding is consistent with the suggestion of Peterson et al. (2001) that, as nitrogen inputs to streams increase, the capacity of streams to effectively retain and transform nitrogen inputs will be overwhelmed, and effects of nitrate loading will be seen farther downstream. Additional research at a subset of our streams also supports this finding, in that denitrification rates in surface water were less than $5 \%$ of surface water nitrate loading rates and were unable to significantly reduce downstream transport of nitrate (Duff et al. 2008). Hence, once within the stream channel, nitrate was effectively transported long distances due to high concentrations, physical stream alterations, and limited bed contact (Duff et al. 2008).

Our results indicate that agricultural streams present some unique challenges for assessing nutrient impacts. Because streams that occur in agricultural lands commonly have substantially elevated nutrient concentrations, it is difficult to find streams with low to moderate nutrient concentrations required for developing predictive models. Most of our study sites had nitrogen and phosphorus concentrations well in excess of criteria values proposed by USEPA (US Environmental Protection Agency 2002b). Despite the high levels of nitrogen and phosphorus, indicative of organically enriched streams, the measurements of Chl $a$ concentrations and in-stream production and respiration are not correspondingly diagnostic of highly productive, eutrophic waters. The results demonstrate that, in these agricultural areas, which ranged from the arid west to humid east, stream metabolism processes are influenced to a greater extent by physical properties of the 
stream or surrounding habitat despite elevated concentrations of nutrients. The study results further suggest that biomass measures likely are not good indicators of stream nutrient enrichment in agricultural settings but still provide a general indication of production levels.

Acknowledgements The authors are grateful for the cooperation of the land owners within each of the study areas and for assistance from the field crews involved in the extensive field activities associated with this study. We would like to thank Charles Schalk (USGS, Augusta, ME) and Jeff Houser (USGS-UMESC, LaCrosse, WI) for their reviews of this paper. Special thanks go to project personnel associated with the development of sampling protocols and software programs used to generate and analyze the dataset. Any use of trade, firm, or product names is for descriptive purposes only and does not imply endorsement by the US government.

Open Access This article is distributed under the terms of the Creative Commons Attribution Noncommercial License which permits any noncommercial use, distribution, and reproduction in any medium, provided the original author(s) and source are credited.

\section{References}

Arar, E. J., \& Collins, G. B. (1997a). U. S. environmental protection agency method 445.0, in vitro determination of chlorophyll $a$ and pheophytin a in marine and freshwater algae by fluorescence, revision 1.2. Cincinnati: U.S. Environmental Protection Agency, National Exposure Research Laboratory, Office of Research and Development.

Arar, E. J., \& Collins, G. B. (1997b). U. S. environmental protection agency method 445.0 , in vitro determination of chlorophyll a and pheophytin a in marine and freshwater algae by fluorescence, revision 1.2.-errata sheet. Cincinnati: U.S. Environmental Protection Agency, National Exposure Research Laboratory, Office of Research and Development.

Bales, J. D., \& Nardi, M. R. (2007). Automated routines for calculation of whole-stream metabolism: Theoretical background and user's guide. U.S. Geological Survey Techniques and Methods Book 4, Chapter C2.

Biggs, B. J. F. (1996). Patterns in benthic algae in streams. In R. J. Stevenson, M. L. Bothworth, \& R. L. Lowe (Eds.), Algal ecology: Freshwater benthic ecosystems (pp. 31-76). San Diego: Academic.

Biggs, B. J. F. (2000). Eutrophication of streams and rivers: Dissolved nutrient-chlorophyll relationships for benthic algae. Journal of the North American Benthological Society, 19, 17-31.

Biggs, B. J. F., \& Kilroy, C. (2000). Stream periphyton monitoring manual. Christchurch: National Institute of Water and Atmospheric Research.

Biggs, B. J. F., Smith, R. A., \& Duncan, M. J. (1999). Velocity and sediment disturbance of periphyton in headwater streams: Biomass and metabolism. Journal of the North American Benthological Society, 18, 222241.

Bott, T. L. (1996). Primary productivity and community response. In F. R. Hauer, \& G. A. Lamberti (Eds.), Methods in stream ecology (pp. 533-556). San Diego: Academic.

Bott, T. L., Brock, J. T., Cushing, C. E., Gregory, S. V., King, D., \& Petersen, R. C. (1978). A comparison of methods for measuring primary productivity and community respiration in streams. Hydrobiologia, 60, $3-12$.

Bott, T. L., Brock, J. T., Dunn, C. S., Naiman, R. J., Ovink, R. W., \& Petersen, R. C. (1985). Benthic community metabolism in four temperate stream systems: An inter-biome comparison and evaluation of the river continuum concept. Hydrobiologia, 123, 3-45.

Bott, T. L., Newbold, J. D., \& Arscott, D. B. (2006). Ecosystem metabolism in Piedmont streams: Reach geomorphology modulates the influence of riparian vegetation. Ecosystems, 9, 398-421.

Brenton, R. W., \& Arnett, T. L. (1993). Methods of analysis by the U.S. Geological Survey National Water Quality Laboratory-Determination of dissolved organic carbon by UV-promoted persulfate oxidation and infrared spectrometry. U.S. Geological Survey Open-File Report 92-480.

Brightbill, R. A., \& Munn, M. D. (2008). Environmental and biological data of the nutrient enrichment effects on stream ecosystems project of the National WaterQuality Assessment Program, 2003-04. U.S. Geological Survey Data Series 345.

Bunn, S. E., Davies, P. M., \& Mosisch, T. D. (1999). Ecosystem measures of river health and their response to riparian and catchment degradation. Freshwater Biology, 41, 333-345.

Chételat, J., Pick, F. R., Morin, A., \& Hamilton, P. B. (1999). Periphyton biomass and community composition in rivers of different nutrient status. Canadian Journal of Fisheries and Aquatic Science, 56, 560-569.

Clarke, K. R., \& Gorley, R. N. (2006). Primer v6: User manual/tutorial. Plymouth: Plymouth Marine Laboratory.

Clawges, R. M., \& Price, C. P. (1999). Digital data set describing surficial geology in the conterminous United States. U.S. Geological Survey OpenFile Report 99-77 [digital map]. http://water.usgs. gov/lookup/getspatial?ofr99-77_geol75m. Accessed April 2003.

Dodds, W. K., \& Welch, E. B. (2000). Establishing nutrient criteria in streams. Journal of the North American Benthological Society, 19, 186-196.

Dodds, W. K., Jones, J. R., \& Welch, E. B. (1998). Suggested classification of stream trophic state: Distributions of temperate stream types by chlorophyll, total nitrogen, and phosphorus. Water Research, 32, 14551462.

Dodds, W. K., Smith, V. H., \& Lohman, K. (2002). Nitrogen and phosphorus relationships to benthic algal biomass in temperate streams. Canadian Journal of Fisheries and Aquatic Science, 59, 865-874. 
Dodds, W. K., Smith, V. H., \& Lohman, K. (2006). Erratum: Nitrogen and phosphorus relationships to benthic algal biomass in temperate streams. Canadian Journal of Fisheries and Aquatic Science, 63, 1190-1191.

Duff, J. H., Tesoriero, A. J., Richardson, W. B., Strauss, E. A., \& Munn, M. D. (2008). Whole stream response to nitrate loading in three streams draining agricultural landscapes. Journal of Environmental Quality, 37, 1133-1144.

Fishman, M. J., ed. (1993). Methods of analysis by the U.S. Geological Survey National Water Quality Laboratory-Determination of inorganic and organic constituents in water and fluvial sediments. U.S. Geological Survey Open-File Report 93-125.

Fitzpatrick, F. A., Waite, I. R., D'Arconte, P. J., Meador, M. R., Maupin, M. A., \& Gurtz, M. E. (1998). Revised methods for characterizing stream habitat in the $\mathrm{Na}$ tional Water-Quality Assessment Program. U.S. Geological Survey Water-Resources Investigations Report 98-4052.

Fuhrer, G. J., Gilliom, R. J., Hamilton, P. A., Morace, J. L., Nowell, L. H., Rinella, J. F., et al. (1999). The quality of our nation's water: Nutrients and pesticides. U.S. Geological Survey Circular 1225.

Hall, C. A. (1972). Migration and metabolism in a temperate stream ecosystem. Ecology, 93, 585-604.

Hall, R. O., \& Tank, J. L. (2003). Ecosystem metabolism controls nitrogen uptake in streams in Grand Teton National Park, Wyoming. Limnology and Oceanography, 48, 1120-1128.

Houser, J. N., \& Mulholland, P. J. (2005). Catchment disturbance and stream metabolism: Patterns in ecosystem respiration and gross primary production along a gradient of upland soil and vegetation disturbance. Journal of the North American Benthological Society, 24, 538-552.

Hunt, C. D. (1979). National Atlas of the United States of America - Surficial Geology. U.S. Geological Survey, NAC-P-0204-75M-O [map].

Johnson, M. R., \& Zelt, R. B. (2005). Protocols for mapping and characterizing land use/land cover in riparian zones. U.S. Geological Survey Open-File Report 20051302.

Kilpatrick, F. A., \& Wilson, J. F. (1989). Measurement of time of travel in streams by dye tracing. Techniques of Water-Resources Investigations of the United States Geological Survey, Book 3, Chapter A9.

Kilpatrick, F. A., Rathbun, R. E., Yotsukura, N., Garker, G. W., \& DeLong, L. L. (1989). Determination of stream reaeration coefficients by use of tracers. Techniques of Water-Resources Investigations of the United States Geological Survey, Book 3, Chapter A18.

King, P. B., \& Beikman, H. M. (1974a). Explanatory text to accompany the geologic map of the United States. U.S. Geological Survey Professional Paper 901.

King, P. B., \& Beikman, H. M. (1974b). Geologic map of the United States (exclusive of Alaska and Hawaii) on a scale of 1:2,500,000. U.S. Geological Survey, 3 color plates.
Lam, L. (2001). An introduction to S-PLUS for windows. Amsterdam: CANdiensten.

Marzolf, E. R., Mulholland, P. J., \& Steinman, A. D. (1994). Improvements to the diurnal upstreamdownstream dissolved oxygen change technique for determining whole-stream metabolism in small streams. Canadian Journal of Fisheries and Aquatic Science, 51, 1591-1599.

McTammany, M. E., Webster, J. R., Benfield, E. F., \& Neatrour, M. A. (2003). Longitudinal patterns of metabolism in a southern Appalachian river. Journal of the North American Benthological Society, 22, 359370.

McTammany, M. E., Benfield, E. F., \& Webster, J. R. (2007). Recovery of stream ecosystem metabolism from historical agriculture. Journal of the North American Benthological Society, 26, 532-545.

Melching, C. S., \& Flores, H. E. (1999). Reaeration equations derived from U.S. Geological Survey database. Journal of Environmental Engineering, 125, 407-414.

Mosisch, T. D., Bunn, S. E., \& Davies, P. M. (2001). The relative importance of shading and nutrients on algal production in subtropical streams. Freshwater Biology, 46, 1269-1278.

Moulton, S. R., II, Kennan, J. G., Goldstein, R. M., \& Hambrook, J. A. (2002). Revised protocols for sampling algal, invertebrate, and fish communities as part of the National Water-Quality Assessment Program. U.S. Geological Survey Open-File Report 02-150.

Mueller, D. K., \& Spahr, N. E. (2006). Nutrients in streams and rivers across the Nation-1992-2001. U.S. Geological Survey Scientific Investigations Report 2006-5107.

Mulholland, P. J., Marzolf, E. R., Webster, J. R., Hart, D. R., \& Hendricks, S. P. (1997). Evidence that hyporheic zones increase heterotrophic metabolism and phosphorus uptake in forest streams. Limnology and Oceanography, 42, 443-451.

Mulholland, P. J., Fellows, C. S., Tank, J. L., Grimm, N. B., Webster, J. R., Hamilton, S. K., et al. (2001). Inter-biome comparison of factors controlling stream metabolism. Freshwater Biology, 46, 1503-1517.

Mulholland, P. J., Helton, A. M., Poole, G. C., Hall, R. O., Jr., Hamilton, S. K., Peterson, B. J., et al. (2008). Stream denitrification across biomes and its response to anthropogenic nitrate loading. Nature, 452, 202 205.

Nakagaki, N., \& Wolock, D. M. (2005). Estimation of agricultural pesticide use in drainage basins using land cover maps and county pesticide data. U.S. Geological Survey Open-File Report 2005-1188.

National Oceanic and Atmospheric Administration (2008). National Climatic Data Center, United States surface data, monthly summary, DS 3220. http://www. ncdc.noaa.gov/oa/mpp/digitalfiles.html. Accessed 30 September 2008.

Odum, H. T. (1956). Primary production in flowing waters. Limnology and Oceanography, 1, 102-117.

Odum, H. T., \& Hoskin, C. M. (1958). Comparative studies on the metabolism of marine waters. Publications of 
the Institute of Marine Science, University of Texas, 5, 16-46.

Ortiz-Zayas, J. R., Lewis, W. M. Jr., Saunders, J. F., III, \& McCutchan, J. H., Jr. (2005). Metabolism of a tropical rainforest stream. Journal of the North American Benthological Society, 24, 769-783.

Patton, C. J., \& Kryskalla, J. R. (2003). Methods of analysis by the U.S. Geological Survey National Water Quality Laboratory-Evaluation of alkaline persulfate digestion as an alternative to kjeldahl digestion for determination of total and dissolved nitrogen and phosphorus in water. U.S. Geological Survey Water-Resources Investigations Report 03-4174.

Peterson, B. J., Wolheim, W. M., Mulholland, P. J., Webster, J. R., Meyer, J. L., Tank, J. L., et al. (2001). Control of nitrogen export from watersheds by headwater streams. Nature, 292, 86-90.

Rabalais, N. N., Turner, R. E., \& Scavia, D. (2002). Beyond science into policy: Gulf of Mexico hypoxia and the Mississippi River. BioScience, 52, 129-142.

Royer, T. V., Tank, J. L., \& David, M. B. (2004). Transport and fate of nitrate in headwater agricultural streams. Journal of Environmental Quality, 33, 1296-1304.

Royer, T. V., David, M. B., Gentry, L. E., Mitchell, C. A., Starks, K. M., Heatherly, T. II, et al. (2008). Assessment of chlorophyll-a as a criterion for establishing nutrient standards in the streams and rivers of Illinois. Journal of Environmental Quality, 37, 437447.

Ruddy, B. C., Lorenz, D. L., \& Mueller, D. K. (2006). County-level estimates of nutrient inputs to the land surface of the conterminous United States, 1982-2001. U.S. Geological Survey Scientific Investigations Report 2006-5012.

Schruben, P. G., Arndt, R. E., \& Bawiec, W. J. (1998). Geology of the conterminous United States at 1:2,500,000 scale: A digital representation of the 1974 P.B. King and H.M. Beikman map. U.S. Geological Survey Data Series 11, [digital data]. http://pubs.usgs.gov/dds/dds11/. Accessed June 1999.

Solar Pathfinder (2002). Instruction manual for the solar pathfinder. Linden: Solar Pathfinder.

Stevenson, R. J., \& Stoermer, E. F. (1981). Quantitative differences between benthic algal communities along a depth gradient in Lake Michigan. Journal of Phycology, 17, 29-36.

Uehlinger, U., \& Brock, J. T. (2005). Periphyton metabolism along a nutrient gradient in a desert river (Truckee River, Nevada, USA). Aquatic Sciences, 67, 507-516.

Uehlinger, U., \& Naegeli, M. W. (1998). Ecosystem metabolism, disturbance, and stability in a prealpine gravel bed river. Journal of the North American Benthological Society, 17, 165-178.

U. S. Department of Agriculture (2002). 2002 Census of Agriculture. National Agricultural Statistics Service.http://www.nass.usda.gov/Census_of_Agriculture/ index.asp. Accessed on 30 April 2007.

U. S. Environmental Protection Agency (1997). Determination of carbon and nitrogen in sediments and particulates of estuarine/coastal waters using elemental analysis, revision 1.4. Cincinnati: U.S. Environmental Protection Agency, National Exposure Research Laboratory, Office of Research and Development.

U. S. Environmental Protection Agency (2000). Nutrient criteria technical guidance manual-Rivers and streams. Washington, D.C.: U.S. Environmental Protection Agency, Office of Water report EPA-822-B00-002.

U. S. Environmental Protection Agency (2002a). National Water Quality Inventory-2000 Report. Washington, D.C.: U.S. Environmental Protection Agency Office of Water report EPA-841-R-02-01. Accessed at http://www.epa.gov/305b/2000report/ on 30 April, 2007.

U. S. Environmental Protection Agency (2002b). Summary table for nutrient criteria documents. Washington, D.C.: U. S. Environmental Protection Agency Office of Water report. http://www. epa.gov/waterscience/criteria/nutrient/ecoregions/files/ sumtable.pdf. Accessed on 31 October, 2008.

U. S. Geological Survey (1999). National land cover data 1992 (NLCD 1992), [digital map]. http://edc.usgs.gov/ products/landcover/nlcd.html. Accessed August 2003.

U. S. Geological Survey and U. S. Environmental Protection Agency (2003). National Hydrography Dataset (NHD) [digital data]. http://nhd.usgs.gov/. Accessed June 2003.

Vogelmann, J. E., Howard, S. M., Limin, Y., Larson, C. R., Wyie, B. K., \& Van Driel, N. (2001). Completion of the 1990's national land cover dataset for the conterminous United States from Landsat Thematic Mapper data and ancillary data sources. Photogrammetric Engineering and Remote Sensing, 67, 650-662.

Wagner, R. J., Boulger, R. W. Jr., Oblinger, C. J., \& Smith, B. A. (2006). Guidelines and standard procedures for continuous water-quality monitors: Station operation, record computation, and data reporting. U.S. Geological Survey Techniques and Methods Report 1-D3, 51 p. +8 attachments. http://pubs.usgs.gov/ tm/2005/tm1D3/pdf/TM1D3.pdf. Accessed 22 May 2006.

Welch, E.B., Jacoby, J.M., Horner, R.R. \& Seeley, M.R. (1998). Nuisance biomass levels of periphytic algae in streams. Hydrobiologia, 157, 161-168.

Wiley, M. J., Osbourne, L. L., \& Larimore, R. W. (1990). Longitudinal structure of an agricultural prairie river system and its relationship to current stream ecosystem theory. Canadian Journal of Fisheries and Aquatic Science, 47, 373-384.

Young, R. G., \& Huryn, A. D. (1996). Interannual variation in discharge controls ecosystem metabolism along a grassland river continuum. Canadian Journal of Fisheries and Aquatic Science, 53, 21992211.

Young, R. G., \& Huryn, A. D. (1999). Effects of land use on stream metabolism and organic matter turnover. Ecological Applications, 9, 1359-1376.

YSI Incorporated (2002). Environmental monitoring systems manual. Yellow Springs: YSI. 